\title{
A Scientific Analysis of Various forms of Chemical Compounds and their use
}

\author{
Prof. Romi Morzelona \\ Professor, Department of Computer Science, \\ Russia \\ romimorzelona@mail.ru
}

\section{Abstract}

In this Research it is talked about that different procedure of Portland concrete assembling. Wet procedure minerals are wet ground to shape a slurry and in dry procedure minerals are dry ground to frame a powder like substance. In this paper, we are talking about the correlation between wet procedure and dry procedure with different favorable circumstances and drawbacks.

Keywords: Portland cement, slurry, lime stone etc.

\section{INTRODUCTION}

There are two kinds of procedure for assembling the concrete are appeared in beneath.

\section{Wet process}

Crude materials are blend in wash plant by 35 to half water. The current Materials are known as slurry that have stream capacity highlights. The furnace size that are required for developed of concrete is higher so the crude material can be blended easily that is the reason well comparative sort of material can be obtained. The creation cost of wet procedure is high and capital expense is moderately less. 


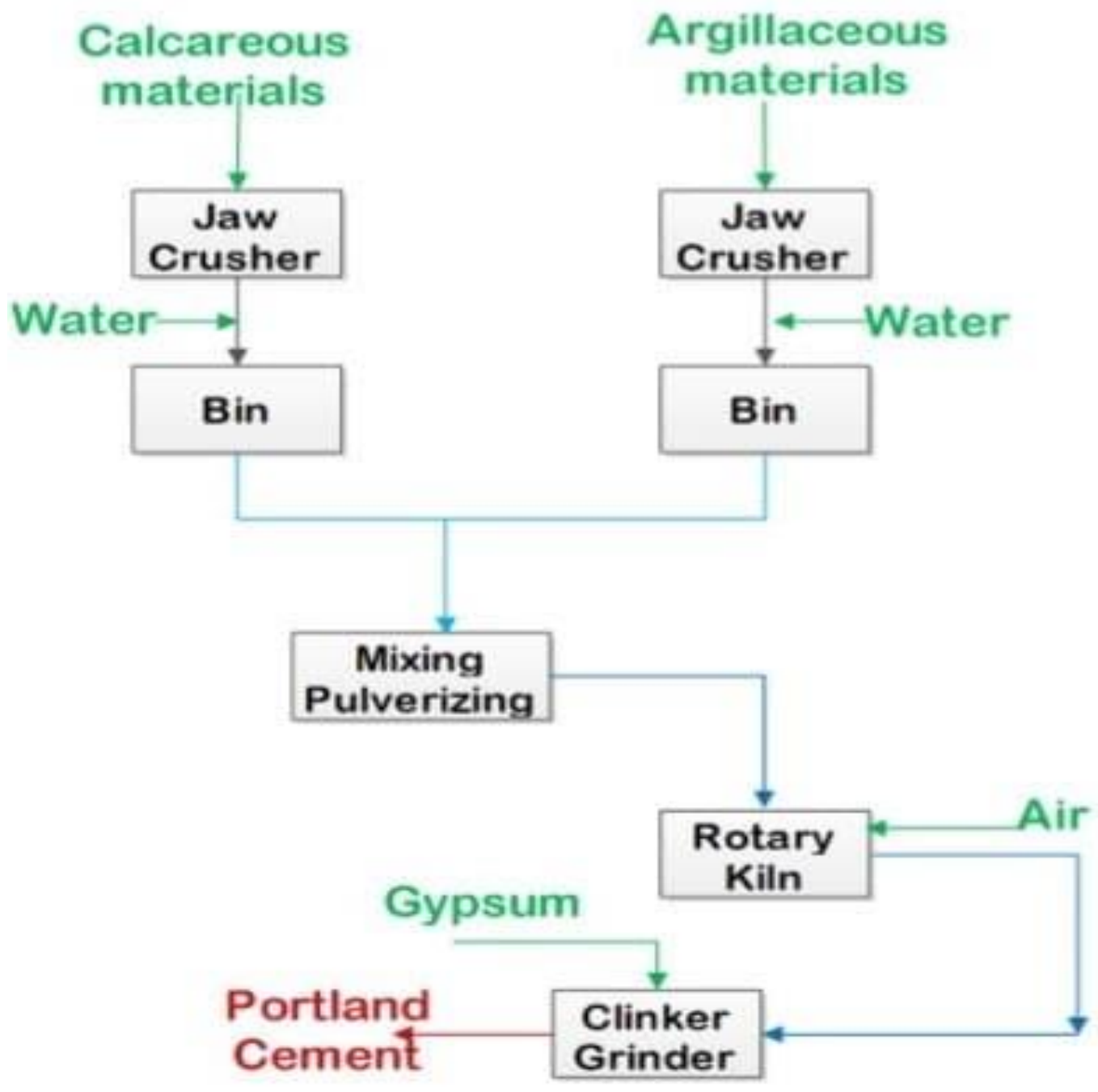

Fig 1: Manufacture of Cement by Wet Process

\section{Dry process}

In the dry process, raw material is mixes in mixers. This dry materials also known as kiln feed. The kiln size are required for built-up of cement is smaller so it is difficult to control Raw materials mixing and it is also challenging to find a well similar material. The production cost is less and capital cost is relatively high because of blender. 


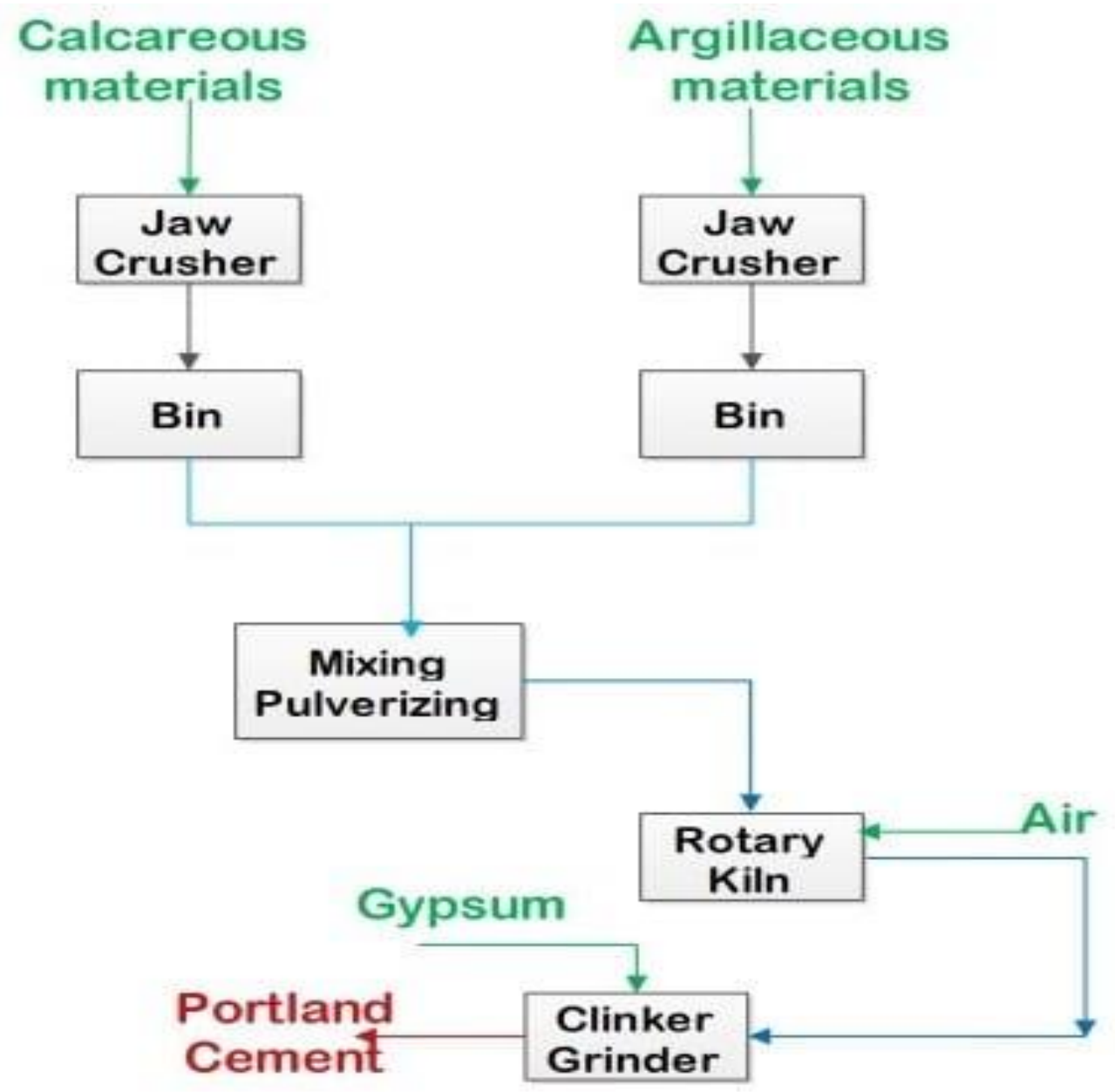

Fig: Manufacture of Cement by Dry Process

Table 1

Raw materials for Portland cement manufacture 


\begin{tabular}{|c|c|c|c|}
\hline $\begin{array}{c}\text { Calcareous } \\
\text { Materials }\end{array}$ & \multicolumn{3}{|c|}{ Argillaceous Materials } \\
\hline Calcium & Silicon & Aluminum & Iron \\
\hline Limestone & Clay & Clay & Clay \\
\hline Marl & Marl & Shale & Iron ore \\
\hline Calcite & Sand & Fly ash & Mill scale \\
\hline Aragonite & Shale & Aluminum ore refuse & Shale \\
\hline Shale & Fly ash & & Blast furnace dust \\
\hline Sea Shells & Rice hull ash & & \\
\hline Cement kiln dust & Slag & & \\
\hline
\end{tabular}

II. DIFFERENCE BETWEEN DRY PROCESS AND WET PROCESS

\begin{tabular}{|c|c|c|}
\hline S.no. & Wet process & Dry process \\
\hline 1. & $\begin{array}{c}\text { When raw material is soft then this method is } \\
\text { used }\end{array}$ & $\begin{array}{c}\text { When raw material is hard then this } \\
\text { method is used }\end{array}$ \\
\hline 2. & $\begin{array}{c}\text { The raw material are changed to powdered } \\
\text { form in the presence of water }\end{array}$ & $\begin{array}{c}\text { The raw material are changed to } \\
\text { powdered form in the of absence } \\
\text { water }\end{array}$ \\
\hline 3. & cement produced-26\% & kement produced-74\% \\
\hline 4. & kilns high fuel needed & More Economically \\
\hline 5. & Less Economically & Need of maintenance is high \\
\hline 6. & Need of maintenance is less & Raw material cannot be easily mix \\
\hline 7. & Raw material can be easily mix & Production cost less \\
\hline 8. & Production cost high & Capital cost is less \\
\hline 9. & Capital cost is less & \\
\hline
\end{tabular}




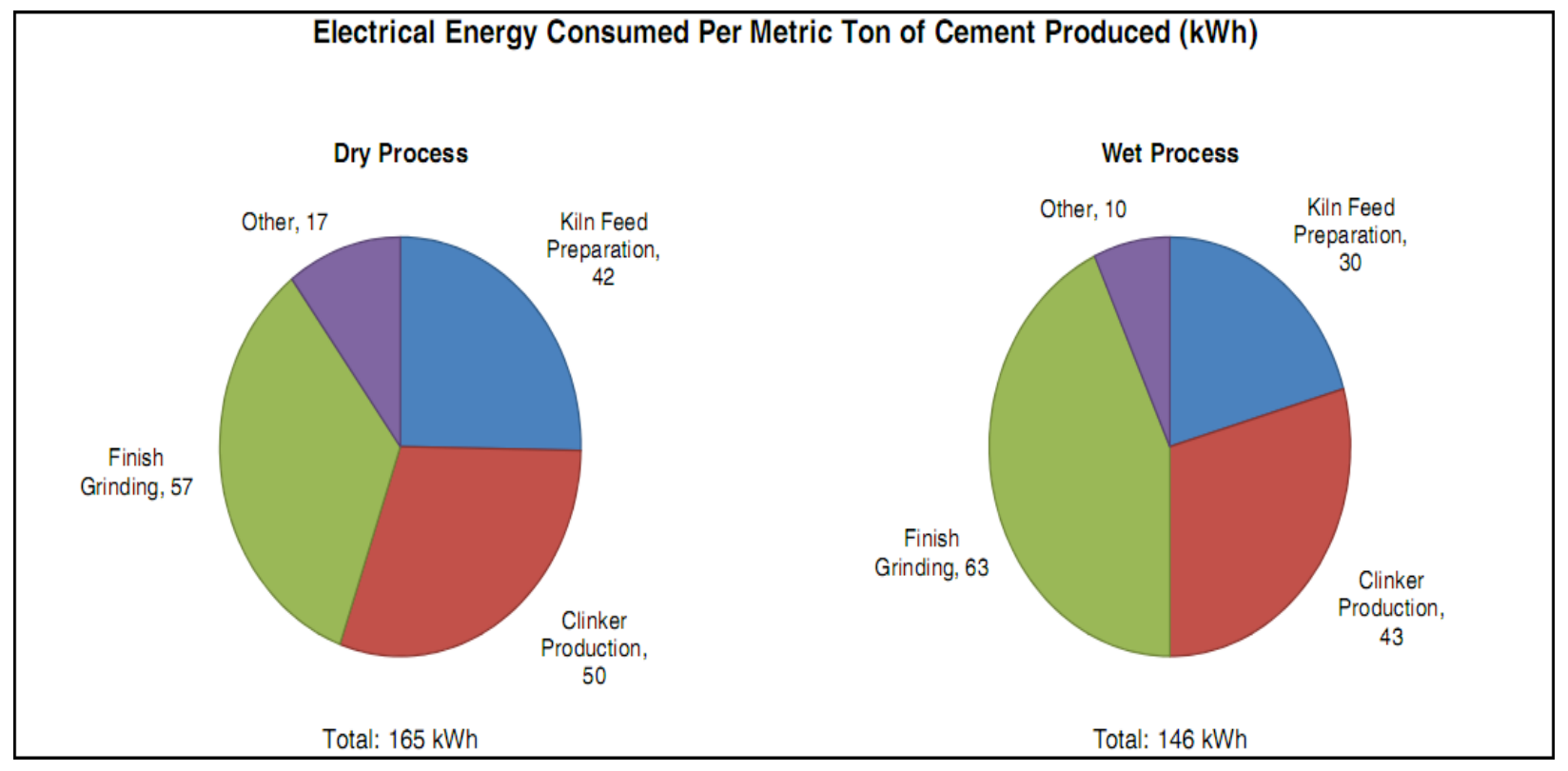

Fig 3: Electrical energy consumed by both process

\section{CONCLUSION}

In this paper we have talked about the wet and dry concrete assembling process. And furthermore we have talked about different crude materials for Portland concrete assembling. This paper shows the examination between wet procedure and dry procedure with different focal points and burdens.

\section{REFERENCES}

[1] C. M. Hanson, "Concrete: the advanced industrial material of the 21st century," Metallurgical \& Materials Transactions A, vol. 26, pp. 1321-1341, 1995.

[2] M. Bediako, S. K. Y. Gawu, and A. A. Adjaottor, "Suitability of some Ghanaian mineral admixtures for masonry mortar formulation," Construction and Building Materials, vol. 29, pp.

667-671, 2012.

[3] S. H. Kosmatka, B. Kerkhoff, and W. C. Panarese, Design and Control of Concrete Mixtures, Portland Cement Association,Skokie, Ill, USA, 14th edition, 2002.

[4] M. S. Mamlouk and J. P. Zaniewski, Materials for Civil andConstruction Engineers, Prentice Hall, Upper Saddle River, NJ,USA, 2006.

[5] T. Punmatharith, M. Rachakornkij, A. Imyim, and M.Wecharatana, "Co-processing of grinding sludge as alternative raw material in portland cement clinker production," Journal

of Applied Sciences, vol. 10, no. 15, pp. 1525-1535, 2010. 
[6] D. N. Huntzinger and T. D. Eatmon, "A life-cycle assessment of Portland cement manufacturing: comparing the traditional process with alternative technologies," Journal of Cleaner Production, vol. 17, no. 7, pp. 668-675, 2009.

[7] F. M. Lea, The Chemistry of Cement and Concrete, Arnold Publishers, London, UK, 3rd edition, 1970.

[8] J. F. Young, S.Mindess, R. J. Gray, andA. Bentur,TheScience andTechnology of Civil Engineering Materials, Prentice-Hall, Upper Saddle River, NJ, USA, 1998.

[9] H. F. W. Taylor, Cement Chemistry, Thomas Telford, London,UK, 2nd edition, 1997.

[10] S. H. Kosmatka and M. L. Wilson, Design and Control of Concrete Mixtures, Portland Cement Association, Stokie, Ill, USA, 2011.

[11] V. Sata, C. Jaturapitakkul, and K. Kiattikomol, "Influence of pozzolan from various by-product materials on mechanical properties of high-strength concrete," Construction and BuildingMaterials, vol. 21, no. 7, pp. 1589-1598, 2007.

[12] A. Neville, Neville on Concrete, ACI, Farmington Hills, Mich, USA, 2003.

[13] R. Fernandez, F. Martirena, and K. L. Scrivener, "The origin of the pozzolanic activity of calcined clay minerals: a comparison between kaolinite, illite and montmorillonite," Cement and

Concrete Research, vol. 41, no. 1, pp. 113-122, 2011.

[14] K. Ganesan, K. Rajagopal, and K. Thangavel, "Evaluation of bagasse ash as supplementary cementitious material," Cement and Concrete Composites, vol. 29, no. 6, pp. 515-524, 2007.

[15] S. Sinthaworn and P. Nimityongskul, "Quick monitoring of pozzolanic reactivity of waste ashes," Waste Management, vol.29, no. 5, pp. 1526-1531, 2009.

[16] J. J. Brooks,M. A.M. Johari, andM.Mazloom, "Effect of admixtures on the setting times of highstrength concrete," Cement and Concrete Composites, vol. 22, no. 4, pp. 293-301, 2000.

[17] X. Fu, Z.Wang,W. Tao et al., "Studies on blended cement with a large amount of fly ash," Cement and Concrete Research, vol. 32,no. 7, pp. 1153-1159, 2002.

[18] E.-H. Kadri, S. Kenai, K. Ezziane, R. Siddique, and G. De Schutter, "Influence of metakaolin and silica fume on the heat of hydration and compressive strength development of mortar," Applied Clay Science, vol. 53, no. 4, pp. 704-708, 2011. 